WSRC-TR-92-142, Rev. 0

Distribution Category: UC-721

Keywords: waste glass

durability, waste glass

acceptance, WAPS,

crystallization, devitrification

\title{
CHARACTERIZATION OF PROJECTED DWPF GLASSES HEAT TREATED TO SIMULATE CANISTER CENTERLINE COOLING (U)
}

WSRC-TR--92-142

DE93 003325

\section{S.L. MARRA AND C.M. JANTZEN \\ c. M Jantzen/y/92}

Approved by

E.W. Holtzscheiter, Manager Defense Waste Processing Technology

Publication Date: May 1992

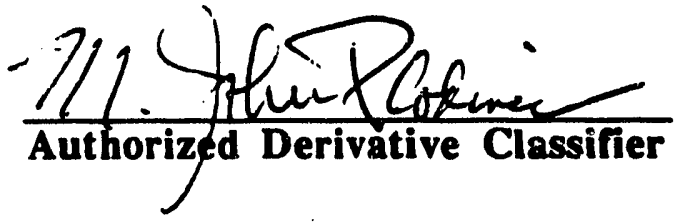

\section{Westinghouse Savannah River Co. Savannah River Site \\ Aiken, SC 29808}

PREPARED FOR THE U.S. DEPARTMENT OF ENERGY UNDER CONTRACT DE-AC09-89SR18035

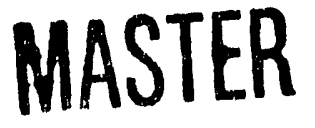


This page intentionally left blank. 


\begin{abstract}
Liquid high-level nuclear waste will be immobilized at the Savannah River Site (SRS) by vitrification in borosilicate glass. The glass will be produced and poured into stainless steel canisters in the Defense Waste Processing Facility (DWPF). Eventually these canistered waste forms will be sent to a geologic repository for final disposal. In order to assure acceptability by the repository, the Department of Energy has defined requirements which DWPF canistered waste forms must meet. These requirements are the Waste Acceptance Preliminary Specifications (WAPS). The WAPS require DWPF to identify the crystalline phases expected to be present in the final glass product. Knowledge of the thermal history of the borosilicate glass during filling and cooldown of the canister is necessary to determine the amount and type of crystalline phases present in the final glass product. Glass samples of seven projected DWPF compositions were cooled following the same temperature profile as that of glass at the centerline of the full-scale DWPF canister. The glasses were characterized by $x$-ray diffraction and scanning electron microscopy to identify the crystalline phases present. The volume percents of each crystalline phase present were determined by quantitative $x$-ray diffraction. The Product Consistency Test (PCT) was used to determine the durability of the heat-treated glasses.
\end{abstract}


This page intentionally left blank. 


\section{TABLE OF CONTENTS}

Page

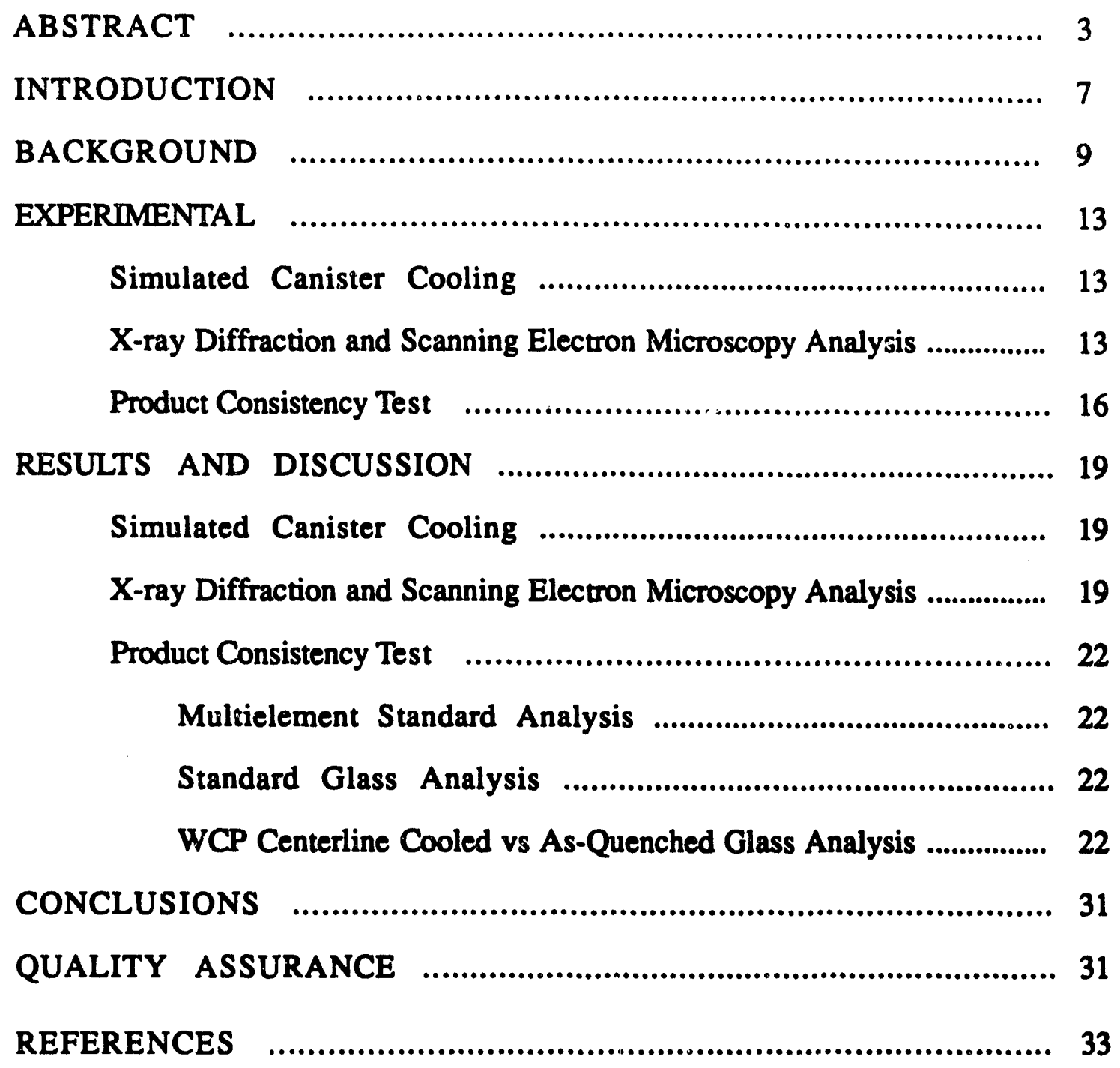


This page intentionally left blank.

$-6-$ 


\section{CHARACTERIZATION OF PROJECTED DWPF GLASSES HEAT TREATED TO SIMULATE CANISTER CENTERLINE COOLING (U)}

\section{INTRODUCTION}

The high-level radioactive waste currently stored in underground carbon steel tanks at the Savannah River Site (SRS) will be immobilized in a durable borosilicate glass in the Defense Waste Processing Facility (DWPF). The canistered waste forms will eventually be sent to a geologic repository for final disposal. The Department of Energy has defined requirements which these canistered waste forms must meet to be acceptable for disposal in the repository.

These requirements are the Waste Acceptance Preliminary Specifications (WAPS). 1 Specification 1.1.1 of the WAPS requires the identification of the crystalline phases expected to be present in the DWPF canistered waste forms. This requires exposure of the seven projected DWPF glasses to the same thermal regimen as is expected for the canistered waste form during and after canister filling.

The seven projected DWPF glass compositions are described in the DWPF Waste Form Compliance Plan (WCP). ${ }^{2}$ Four of these compositions have been projected from existing high-level waste inventory while three of them are hypothetical glass compositions. The three hypothetical glasses are the design-basis waste (blend), high aluminum (HM) waste, which represents the upper design limit of glass viscosity, and Purex (high iron) waste, which represents the lower design limit of glass viscosity. 2,3 The Purex represents a possible worstcase composition.

In order to provide the necessary information required by the WAPS, large quantities of the seven simulated waste glasses from the WCP were fabricated. The chemical analyses of the seven glass compositions are shown in Table 1.

To comply with Specification 1.1.1 of the WAPS, samples of the projected glasses were exposed to the thermal regimen recorded during simulation of full scale canister production. The amount of crystallization present was measured quantitatively. The quantitative leach rate enhancement for the glasses exposed to the thermal regimen was determined by comparing the durability of the devitrified glasses to nondevitrified, i.e., quenched glasses, using the Product Consistency Test (PCT). 
Table 1.

DWPF Projected Compositions*

Glass

Components

$\mathrm{Wt} \%$

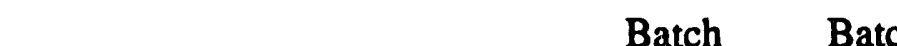

$\mathrm{Al}_{2} \mathrm{O}_{3}$

Blend

HM Purex

$\# 1 \quad$ \#2

$\# 2$

Batch \#3

Batch

$\mathrm{B}_{2} \mathrm{O}_{3}$

4.16

7.15

2.99

4.88

4.63

3.44

3.43

$\mathrm{BaO}$

8.05

7.03

10.33

7.78

7.88

7.69

8.14

$\mathrm{CaO}$

0.18

0.11

0.20

0.15

0.16

0.18

0.25

$\mathrm{Cr}_{2} \mathrm{O}_{3}$

1.03

1.01

1.09

1.22

1.08

0.99

0.84

$\mathrm{Cs}_{2} \mathrm{O}$

0.13

0.09

0.15

0.11

0.13

0.14

0.14

$\mathrm{CuO}$

0.08

0.06

0.06

0.06

0.02

0.06

0.09

$\mathrm{Fe}_{2} \mathrm{O}_{3} \quad 10.91$

0.25

0.42

0.40

0.42

0.40

0.45

$\mathrm{K}_{2} \mathrm{O}$

3.68

7.78

13.25

12.84

11.12

11.71

11.71

$\mathrm{Li}_{2} \mathrm{O}$

4.44

2.21

3.41

3.33

3.38

3.40

3.86

$\mathrm{MgO}$

1.41

4.62

3.22

4.43

4.50

4.51

4.29

$\mathrm{MnO}_{2}$

2.05

1.49

1.41

1.42

1.42

1.42

1.43

$\mathrm{MoO}_{3}$

0.15

2.15

2.07

2.11

1.73

1.87

3.11

$\begin{array}{ll}0.22 & 0.08\end{array}$

0.11

0.17

0.12

0.20

$\mathrm{Na}_{2} \mathrm{O}$

9.13

8.56

12.62

9.00

9.21

9.01

9.16

$\mathrm{Nd}_{2} \mathrm{O}_{3}$

0.22

0.55

0.06

0.15

0.26

0.17

0.39

$\mathrm{NiO}$

0.89

0.41

1.19

0.75

0.90

1.0 .5

1.06

$\mathrm{RuO}_{2}$

0.03

0.04

0.01

0.02

0.04

0.03

0.05

$\mathrm{SiO}_{2} \quad 51.9$

$55.8 \quad 46.5$

50.2

52.1

52.6

50.1

$\mathrm{TiO}_{2}$

0.89

0.56

0.68

0.68

0.69

0.68

1.03

$\mathrm{ZO}_{2}$ 0.14

0.33

0.05

0.10

0.17

0.12

0.22

Total

$99.91 \quad 100.42$

99.79

99.74

100.01

99.59

99.95

* Glasses produced and analyzed by Coming Engineering Laboratory Services as a Level 1 procurement, CELS Report 11988-027 (DPSTN-4771 and WSRC-NB-90-392). 


\section{BACKGROUND}

Since the late 1970's, experimental glass melters have been used to develop the vitrification process for the immobilization of high-level liquid waste (HLLW) in the DWPF. Full scale DWPF prototypic canisters were filled during the Large Slurry Fed Melter (LSFM) and Scale Glass Melter (SGM) campaigns. During one of the LSFM campaigns a canister was instrumented with thermocouples to measure canister surface and centerline temperatures. Canister centerline temperatures were measured at heights of 15", 27", 39", 51", 63", 75", and $87 " .4$ The canister was filled at a nominal $240 \mathrm{lb} / \mathrm{hr}$ feed rate.

Full scale DWPF canisters were also filled during the Scale Glass Melter (SGM) campaigns. During the eighth SGM campaign, three of the canisters filled were instrumented with thermocouples to determine axial and radial canister temperature profiles during filling and cooldown of the canisters. 5 Two of the canisters were filled under continuous pour conditions at the DWPF glass pour rate of $240 \mathrm{lbs} / \mathrm{hr}$. Canister centerline temperatures were measured at heights of 15", 27", 39", 51", 63", 75", and 87".

The centerline temperature profiles obtained during the SGM work were compared to those from the canister produced under simulated DWPF conditions with the LSFM. The two sets of data were in reasonable agreement. The SGM work was performed prior to implementation of a comprehensive Quality Assurance Program. Thus, this data was qualified ${ }^{6}$ prior to using it for this study. The SGM data was qualified by comparing it to the earlier LSFM canister temperature profile study. As a result of this review, it was concluded that the uncertainty in the SGM centerline cooling curve at a height of $51^{\prime \prime}$ was only $\pm 20^{\circ} \mathrm{C}$. The centerline temperature measurements made at a height of 51" were chosen as the "worst case," since at that location the glass cools at the slowest rate.

Centerline-cooled heat treatments had been conducted on earlier SRL waste glass formulations ${ }^{7-10}$ using the first set of canister centerline temperature profiles ${ }^{4}$. The devitrification occurring in the glasses heat treated to simulate canister cooling was measured by quantitative $\mathrm{x}$-ray diffraction (XRD) analysis. For high $\mathrm{SiO}_{2}$ containing glasses, like the family of 165 frit glasses mixed with varying types of SRS HLLW, about 5-10 volume percent spinel (nominally $\mathrm{NiFe}_{2} \mathrm{O}_{4}$ ) and $15-18$ volume percent acmite (nominally $\mathrm{NaFeSi}_{2} \mathrm{O}_{6}$ ) crystallized (Table 2). For higher $\mathrm{Na}_{2} \mathrm{O}$ containing glasses, such as the family of 131 frit glasses mixed with varying types of SRS HLLW, less spinel and acmite crystallized but higher concentrations of nepheline (nominally $\mathrm{NaAlSiO}_{4}$ ) crystallized (Table 2). The relative amounts of spinel, acmite, and nepheline which crystallized were dependent on the amc'ant of $\mathrm{Fe}_{2} \mathrm{O}_{3}$ or $\mathrm{Al}_{2} \mathrm{O}_{3}$ in the waste being vitrified, and the total amount of $\mathrm{Si}_{2} \mathrm{O}$ and $\mathrm{Na}_{2} \mathrm{O}$ in the glass, including the $\mathrm{SiO}_{2}$ and $\mathrm{Na}_{2} \mathrm{O}$ contributions from both the waste and the frit being vitrified.

The durability of the quenched and centerline-cooled devitrified glasses of each composition listed in Table 2 were compared by means of a 24-hour static leach test developed by Corning, Inc. for crushed glass and by a 28-day static scoping leach test suggested by the Materials Characterization Center (MCC-1P) for monoliths of glass. ${ }^{11}$ 
Table 2.

Volume Percent Devitrification of Simulated Canister Centerline-Cooled (Sludge Only) Glasses Determined by Quantitative X-ray Diffraction (from Ref. 9,10)*

$\begin{array}{lllll}\begin{array}{l}\text { Glass } \\ \text { Type }\end{array} & \begin{array}{l}\text { Waste } \\ \text { Type }\end{array} & \begin{array}{l}\text { Spinel } \\ (\text { Vol\%) }\end{array} & \begin{array}{l}\text { Acmite } \\ \text { Vol\%) }\end{array} & \begin{array}{l}\text { Nepheline } \\ \text { (Vol\%) }\end{array} \\ 165 & \begin{array}{l}\text { HM } \\ \text { (high Al) }\end{array} & 5 & 0 & 0 \\ 165 & \begin{array}{l}\text { Average } \\ 165\end{array} & 5-8 & 10-20 & 0 \\ 131 & \begin{array}{l}\text { Purex } \\ \text { (high Fe) }\end{array} & 8-12 & 18 & 0 \\ 131 & \begin{array}{l}\text { Hur } \\ \text { (high Al) }\end{array} & 0 & 0 & 35-40 \\ 131 & \begin{array}{l}\text { Average } \\ \text { Purex } \\ \text { (high Fe) }\end{array} & 6 & 4 & 13 \\ & & 10 & 0 & 14-16\end{array}$

* error $\pm 2 \%$ spinel, $\pm 5 \%$ acmite, $\pm 10 \%$ nepheline; all data confirmed by optical microscopy and scanning electron microscopy 
Crystallization of spinel was shown not to affect glass durability, while crystallization of large amounts of the alkali silicate phases (acmite and/or nepheline) were shown to significanily increase leachability. For the 165 average glasses devitrified during cooling regimens simulating canister centerline cooldown, the total of $\sim 25$ volume percent crystallization increased the boron release by $2-3 \mathrm{X}$ relative to the boron release of a nondevitrified, i.e quenched, glass. ${ }^{9}$ For the 131 average and high $\mathrm{Fe}$ containing glasses devitrified by a canister centerline cooling regimen, the appearance of the additional alkali silicate phase, nepheline, caused a $5 \mathrm{X}$ increase in the boron release relative to a nondevitrified glass of the same composition. ${ }^{9}$

The durability of these earlier SRS glass formulations were examined using leach tests that were not developed specifically to examine glass consistency and homogeneity, e.g. the one day Corning crushed glass durability test and the MCC-1P monolithic durability test. ${ }^{9}$ A new 7 day crushed glass durability test, designated the Product Consistency Test (PCT), has been developed for glasses produced in the DWPF. ${ }^{12-18}$ The test was designed to be sensitive to glass composition and homogeneity in order to evaluate the product consistency requirements of the WAPS ${ }^{1}$ and to evaluate the effect of heat treatments on glass durability. The PCT was developed, in part, to satisfy the WAPS requirements by providing a test which is (1) sensitive to glass composition and homogeneity, and (2) has the potential to be related to repository sitespecific release tests. The test was designed to provide confirmation of the consistency of DWPF glass while considering the following:

- sensitivity of the test to glass composition and homogeneity

- time necessary to demonstrate product quality

- ease of sample preparation for radioactive glass

- ease of test procedure for remote operation

- precision of the test results

- acceptance by waste form developers and repository projects

The earlier SRS glasses studied ${ }^{7-10}$ were sludge-only glasses fabricated from 28 wt\% HLLW on a dry basis and $72 \mathrm{wt} \%$ glass making frit. Process changes at SRS to acccimmodate in-tank precipitation of Cs-137 necessitated formulation of new frit compositions. ${ }^{19}$ Due to the intank precipitation, an additional waste stream, composed primarily of $8 \mathrm{wt} \% \mathrm{Na}_{2} \mathrm{O}, \mathrm{K}_{2} \mathrm{O}$ and $\mathrm{B}_{2} \mathrm{O}_{3}$ was incorporated into the glass composition. Since the waste stream components were the same or similar to the alkali and boron in the frit, lower amounts of frit could be used to make glasses of similar composition to the sludge-only glasses by using the same $28 \mathrm{wt} \%$ waste, $8 \mathrm{wt} \%$ frit components from the new precipitate hydrolysis aqueous (PHA) process, and only $64 \mathrm{wt} \%$ frit.

The PHA process frit formulations were recalculated to be similar to the sludge-only process glasses. ${ }^{19}$ The 202 glass (frit $202+$ PHA + sludge) was formulated to be chemically and physically similar to 165 glass (frit $165+$ sludge). The alkali and boron substitutions made, curing the development of frit 202 were done on a weight percent basis rather than a mole percent basis. Hence, the 202 PHA glasses are actually somesyhat higher in $\mathrm{SiO}_{2}$ and lower in alkali than the 165 sludge-only glasses. 
The 202 PHA frits were combined with the most recent waste tank composition projections and these were used to formulate the PHA glasses in the WCP given in Table 1. The three hypothetical glasses in the WCP are the design-basis waste (blend), high aluminum (HM) waste, and Purex (high iron) waste, which rcpresents a possible worst-case composition.

The current study was initiated to address the WAPS specification 1.1.1 which require that the DWPF determine the phases expected to be present in the DWPF glass product. The study also determined the effects of crystallization on glass durability (measured by the PCT). This study differed from earlier studies through use of

- updated canister centerline cooling curves

- updated quantitative $\mathrm{x}$-ray diffraction calibration curves

- the seven PHA glasses from the WCP, which span the range of compositions that may be processed in DWPF

- the Product Consistency Test (PCT), which is more sensitive to glass homogeneity and more precise than previously available glass durability tests 


\section{EXPERIMENTAL}

\section{Simulated Canister Centerline Cooling}

In order to provide the necessary information required by the WAPS, Corning, Inc. was contracted to supply large quantities of the seven simulated waste glasses from the WCP. The Group A waste components are predominantly $\mathrm{Mo}$ and were added to the glass as $\mathrm{MoO}_{3}$. The Group B waste components are predominately $\mathrm{Nd}$ and $\mathrm{Zr}$. These were added to the glass in the rat $\mathrm{O}$ of $2: 1$ as $\mathrm{Nd}_{2} \mathrm{O}_{3}$ and $\mathrm{ZrO}$. All of the sodium, calcium, and barium compourds were added as their oxide equivalents for simplicity. Corning, Inc. was unable to handle uranium containing glasses and so the $\mathrm{U}_{3} \mathrm{O}_{8}$ component of the WCP glasses ${ }^{6}$ was omitted and the glass compositions renormalized. Reference amounts of the minor Ru component were added as $\mathrm{RuO}_{2}$. The Corning analyses of the seven giass compositions as fabricated is shown in Table 1.

In order to simulate centerline canister cooling the WCP glasses were exposed to the temperature profile measured at the centerline of the prototypic DWPF canister during the eighth campaign of the SGM. The centerline temperature measurements made at a height of 51 " were chosen as the "worst case" since at that location the glass cools at the slowest rate.

Two samples of each of the glass compositions were heat-treated in separate furnace runs to simulate canister cooling. Two furnace runs were used to compensate for any variation. Approximately 60 grams of glass was placed in a covered high purity $(99.8 \%)$ alumina crucible. The crucibles were placed in a Lindberg programnable furnace and melted at the DWPF melt temperature of $1150^{\circ} \mathrm{C}$ for four hours. The glasses were then cooled according to the thermal regimen shown in Figure 1. As can be seen in the figure the furnace temperature profile was within $20^{\circ} \mathrm{C}$ of the temperatures measured at a height of $51^{\prime \prime}$ at the centerline of the canister filled during the SGM campaign.

In order to simulate quenched glass which may be found at the outer surface of the canister, the as-received glass from Corning was remelted and quenched. Approximately 60 grams of each of the seven DWPF projected compositions was placed in a covered high purity (99.8\%) alumina crucible. The crucibles were placed in the same Lindberg furnace discussed above and melted at $1150^{\circ} \mathrm{C}$ for four hours. After melting, the glasses were removed from the furnace and air cooled rapidly to room temperature.

\section{X-ray Diffraction and Scanning Electron Microscopy Analysis}

Scanning electron microscopy (SEM) coupled with energy dispersive analysis by $\mathrm{x}$-ray (EDAX) was used to determine the phase compositions of the crystallizing phases in the centerline cooled WCP glasses. Determination of the approximate phase composition of these solid solutions was necessary before preparation of the phase pure standards for quantitative $x$ ray diffraction $(X R D)$ analysis.

Scanning electron microscopy with EDAX indicated that the spinel which crystallized in the WCP glasses was the nominal $\mathrm{NiFe}_{2} \mathrm{O}_{4}$ containing some $\mathrm{Cr}, \mathrm{Ti}$ and $\mathrm{Mn}$ as observed in previous studies. ${ }^{7-10}$ Therefore, phase pure $\mathrm{NiFe}_{2} \mathrm{O}_{4}$ was fabricated synthetically from $\mathrm{NiO}$ 


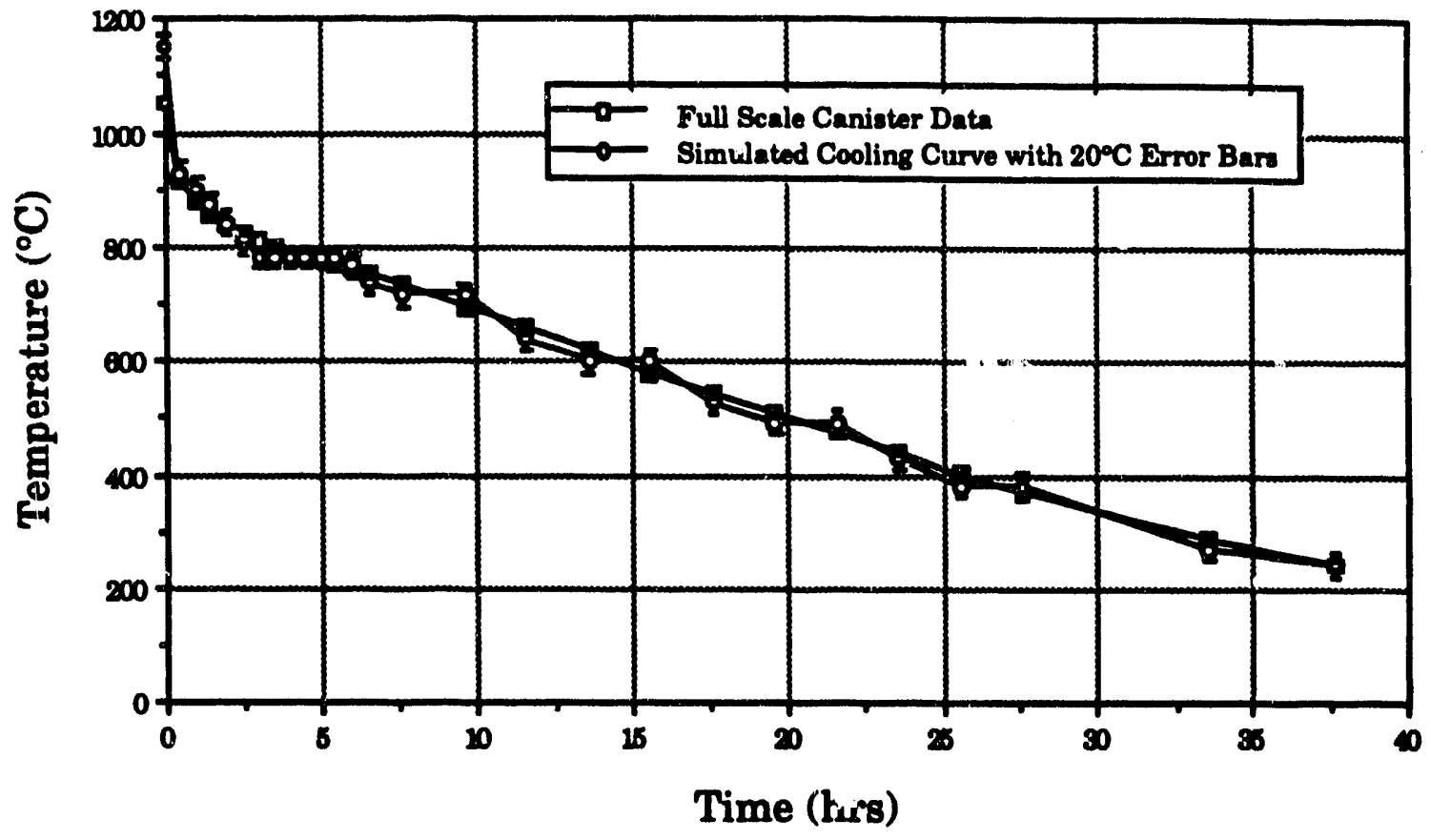

Figure 1.

Full Scale and Simulated Centerline Cooling Curves 
and $\mathrm{Fe}_{2} \mathrm{O}_{3}$ at $1400^{\circ} \mathrm{C}$ for 4 days and used to prepare the quantitative $\mathrm{x}$-ray diffraction standards.

The SEM/EDAX analysis indicated that the acmite that crystallized in the WCP glasses was nor the nominal $\mathrm{NaFeSi}_{2} \mathrm{O}_{6}$ observed in previous studies ${ }^{7-10}$ because it contained considerable $\mathrm{Ca}$, $\mathrm{Ti}$, and $\mathrm{K}$. A natural acmite was obtained from Ward's Scientific and used to prepare the quantitative $\mathrm{x}$-ray diffraction standards.

The nepheline phase, nominally $\mathrm{NaAlSiO}_{4}$ was not observed in SEM/EDAX analysis. Repeated attempts at preparing phase pure nepheline from batch chemicals were unsuccessful due to the incongruent melting of this phase. ${ }^{20}$ Fabrication of phase pure $\mathrm{NaAlSiO}_{4}$ by sol-gel techniques is in progress. For the purposes of this study, the quantitative amounts of repheline were calculated by the reference intensity method. ${ }^{21-23}$

Quantitative x-ray analysis for $\mathrm{NiFe}_{2} \mathrm{O}_{4}$ was performed by developing $\mathrm{x}$-ray calibration curves from six standards ${ }^{1}$ made by mixing both known weight and volume fractions of the phase pure components with nondevitrified Blend glass. The "internal standard" quantitative technique was used and $10 \mathrm{wt} \% \mathrm{Si}$ added to each standard and each unknown. ${ }^{24}$ The Si (III) Bragg reflection was chosen as the internal standard because it did not interfere with any of the major peaks of $\mathrm{NiFe}_{2} \mathrm{O}_{4}$, acmite, or nepheline.

The volume percent calibrations used in this study for $\mathrm{NiFe}_{2} \mathrm{O}_{4}$ are curved versus the more common representation in weight percent. Curvature of the volume percent calibrations is due to the significant differences in density between the glass and the spinel. In previous studies ${ }^{7-}$ 10 the volume percent calibrations exhibited more curvature because of the density difference coupled with the effects of plotting the volume percent $\mathrm{NiFe}_{2} \mathrm{O}_{4}$ in the phase-pure standards against the ratio of the integrated area of a $\mathrm{NiFe}_{2} \mathrm{O}_{4}$ standard peak divided by the integrated area of a Si standard peak which is then normalized by the integrated area of the Si standard peak in the glass alone. Use of the normalization accounts for the interferences in the mass adsorption coefficients of the glass, the $\mathrm{NiFe}_{2} \mathrm{O}_{4}$, and the $\mathrm{Si}$ standard $\mathrm{d}^{25}$ as well as for differences in diffractometer parameters, diffractometer geometry, and sample preparation between laboratories and reseurchers.

Volume percent calibration curves were developed for the most intense $\mathrm{NiF}_{2} \mathrm{O}_{4} \mathrm{Bragg}$ reflection, the (311) 25 which can be used for quantitative analysis in the absence of acmite or corrected for acmite interference when acmite is present, and for the less intense (440) used in previous studies $^{7-10}$ which can be used in the presence of acmite.

An additional set of sixteen $\mathrm{NiFe}_{2} \mathrm{O}_{4}$ standards, ${ }^{2}$ containing $10 \mathrm{wt} \% \mathrm{Si}$, were also used to

$5.55,11.1,22.2,33.3,44.4,55.5 \mathrm{wt} \% \mathrm{NiFe}_{2} \mathrm{O}_{4}$

$22,4,6,8,10,12,14,16,18,20,25,30,35,40,45,50$ volume $\% \mathrm{NiFe}_{2} \mathrm{O}_{4}$ in Blend 1 glass which corresponds to a range of 4 to $66.4 \mathrm{wt} \% \mathrm{NiFe}_{2} \mathrm{O}_{4}$ 
verify the initial calibration curves over a larger compositional range. The volume percent determinations given in this study were made from the volume percent calibration curves based on six standards. The use of the weight percent calibration curves would have allowed for linearization of the data through the origin and enhanced the accuracy based on fewer standards. Calibration curves were developed for the $\mathrm{NiFe}_{2} \mathrm{O}_{4}$ (311) and (440) Bragg reflections as discussed above.

A set of three acmite standards, ${ }^{3}$ containing $10 \mathrm{wt} \% \mathrm{Si}$, were used to determine weight percent and volume percent calibration curves. Calibration curves were developed for the two most intense Bragg reflections, the (121) and the $(310)^{26}$ which can be used for quantitative analysis in the absence of nepheline and for the less intense (110) used in previous studies ${ }^{7-10}$ which can be used in the presence of nepheline.

\section{Product Consistency Test}

The seven duplicate centerline cooled glasses and seven as quenched glasses from the WCP were examined using Version 3.0 of the PCT. ${ }^{18}$ In the PCT analysis, crushed glass of $100-$ 200 mesh is immersed in ASTM Type I water for 7 days at $90^{\circ} \mathrm{C}$. The volume of solution (V) used was the recommended $10 \mathrm{~mL}$ per gram of glass. Leachates were filtered to remove colloids and/or particulates. The leachates were analyzed for $\mathrm{pH}$ and the elemental concentration of the glass species of interest.

A standard glass, ARM-1 was used as a control to eliminate long term bias in the experimental analysis and in the analytical data. Duplicate PCT centerline cooled glass analyses and triplicate as quenched glass analyses were performed along with triplicate glass standards which were run simultaneously.

A multielement solution standard was used during the centerline cooled PCT leachate aralysis to ensure that instrumental drift did not significantly bias the short term analysis of the leachates. Durability tests containing ASTM Type I water but no glass samples were run simultaneously to all the glasses as "blanks." The use of blanks ensure that test vessel preparation was adequate and that the sample leachates can be corrected for elemental variation occurring independently of the glass-solution interactions.

The leachate concentrations are reported as normalized elemental mass losses, $\mathrm{NC}_{\mathbf{j}}$, released from the glass in grams of glass per $L$ of leachant. This has the advantage that the release concentrations in parts per million are normalized by the weight fraction of that element present in the glass.

The expression below for normalized elemental mass loss, $\mathrm{NC}_{\mathrm{i}}$ has been used in this study.

$$
N C_{i}=\frac{C_{i-}}{F_{i}}
$$

where

$$
\mathrm{NC}_{\mathrm{i}}=\text { normalized elemental mass loss (gglass } \mathrm{L} \text { ) }
$$

\footnotetext{
$2.59,5.00$, and $10.67 \mathrm{wt} \% \mathrm{acmite}$
} 


$$
\begin{aligned}
& C_{i}=\quad \begin{array}{l}
\text { mass of element " } i \text { " in the solution corrected for the } \\
\text { average mass of element " } i \text { " in the blanks }\left(g_{i} / m^{3}\right)
\end{array} \\
& F_{i}=\text { fraction of element " } i \text { " in the glass }\left(g_{j} / g_{\text {glass }}\right)
\end{aligned}
$$

The surface area of the glass and the solution volume are constant during PCT analyses and, therefore, do not appear in equation 1. 
This page intentionally left blank.

$-18-$ 


\section{RESULTS AND DISCUSSION}

\section{Simulated Canister Cooling}

The furnace temperature profile used to simulate centerline canister cooling was within $20^{\circ} \mathrm{C}$ of the temperature measurements made on the DWPF prototypic canister filled during the eighth campaign of the SGM (Figure 1).

\section{X-ray Diffraction and Scanning Electron Microscopy Analysis}

The quantitative $\mathrm{x}$-ray diffraction analysis indicated that there was less than 3.5 volume percent crystallization in any of the centerline cooled WCP glasses (Table 3). Because of the small volume fractions of spinel present the most intense $x$-ray diffraction Bragg reflection, the (311), had to be used rather than the (440) reflection used in previous studies ${ }^{7-10}$ and recommended in the task plan ${ }^{27}$. Likewise, the most intense $x$-ray diffraction reflection, the (121), had to be used for the acmite determinations rather than the less intense (110) and (221) used in previous studies ${ }^{7-10}$ and recommended in the task plan $^{27}$ because of the small volumes present and lack of interference from other phases.

The glasses based on blended waste (Blend-1 and Batches 1-4) crystallized primarily spinel and smaller amounts of acmite except for the Batch 3 glasses in which the amount of spinel and acmite was about equal. Batch 3 and 4 glasses had the highest total amount of crystallization, approximately 3.1-3.2 volume percent. The high alumina waste glass (HM) primarily crystallized more acmite than spinel while the high iron waste glass (Purex) crystallized primarily nepheline.

The WCP glasses are more resistant to devitrification than the previously tested sludge only glasses ${ }^{7-10}$ due to their higher $\mathrm{SiO}_{2}$ content ${ }^{19}$ and concomitant higher melt viscosity. ${ }^{28}$ Comparing Table 2 and Table 3 demonstrates that the average WCP glasse $s$ and the high alumina (HM) containing WCP glasses mimic the phase assemblages of the sludge only 165 glasses but at much lower concentrations of acmite and spinel. The WCP high iron containing Purex glasses mimic the phase assemblages observed in the sludge only 131 high iron glasses. Although the WCP high iron (Purex) glass is formulated with the same high $\mathrm{SiO}_{2}$ containing 202 frit that the remaining WCP glasses were formulated with, the updated Purex waste composition is much higher in $\mathrm{Na}_{2} \mathrm{O}$ than the Purex waste simulations used in the previous sludge-only studies. ${ }^{7-10}$

The phases identified during the scanning electron microscopy analyses were consistent with the x-ray diffraction phase identifications (Table 4) except in the case of nepheline. Nepheline was identified in the Purex glass during the XRD analysis but could not be identified in SEM. Nepheline was probably not observed in the SEM/EDAX analysis because of the low volume fractions of this phase present in the Purex glass $(<1.5$ vol\%; Table 3). In addition, the observation of nepheline by SEM/EDAX is limited by the lack of phase contrast and the similarity of the EDAX spectra for this phase to EDAX spectra of the glass matrix. Small amounts of spinel and acmite were identified in the Purex glass by SEM which were not detected during the XRD analysis. 
Table 3.

Volume Percent Devitrification of Simulated Canister Centerline-Cooled WCP Glasses Determined by Quantitative X-ray Diffraction

\begin{tabular}{|c|c|c|c|c|}
\hline WCPGLASS & $\begin{array}{l}\text { SPINEL } \\
\text { (3W) }\end{array}$ & $\begin{array}{l}\text { ACMITE } \\
\text { (121) }\end{array}$ & $\begin{array}{l}\text { NEPHEI.NE } \\
(201)^{*}\end{array}$ & $\begin{array}{l}\text { TOTAL } \\
\text { YOL } \%\end{array}$ \\
\hline BLEND 1-1-7-1 & 1.6 & 0.9 & BDL & 2.5 \\
\hline BLEND 1-1-7-2 & 1.5 & 0.7 & BDL & 2.2 \\
\hline BLEND 1-2-7-1 & 1.6 & BDL & BDL & 1.6 \\
\hline BLEND 1-2-7-2 & 1.9 & 0.8 & BDL & 2.7 \\
\hline AVERAGE & 1.7 & 0.8 & & 2.3 \\
\hline STANDARD DEV & 0.2 & 0.1 & & 0.5 \\
\hline BATCH 1-1-7-1 & 1.6 & 1.0 & BDL & 2.6 \\
\hline BATCH 1-1-7-2 & 1.4 & 0.9 & BDL & 2.3 \\
\hline BATCH 1-2-7-1 & 1.6 & 0.8 & BDL & 2.4 \\
\hline BATCH 1-2-7-2 & 1.6 & 0.8 & BDL & 2.4 \\
\hline AVERAGE & 1.6 & 0.9 & & 2.4 \\
\hline STANDARD DEV & 0.1 & 0.1 & & 0.1 \\
\hline BATCH 2-1-7-1 & 1.7 & 0.9 & BDL & 2.6 \\
\hline BATCH 2-1-7-2 & 1.9 & 1.1 & BDL & 3.0 \\
\hline BATCH 2-2-7-1 & 1.8 & 0.8 & BDL & 2.6 \\
\hline BATCH 2-2-7-2 & 1.8 & 0.7 & BDL & 2.5 \\
\hline AVERAGE & 1.8 & 0.9 & & 2.7 \\
\hline STANDARD DEV & 0.1 & 0.2 & & 0.2 \\
\hline BATCH 3-1-7-1 & 1.5 & 1.1 & BDL & 2.6 \\
\hline BATCH 3-1-7-2 & 1.5 & 1.2 & BDL & 2.7 \\
\hline BATCH 3-2-7-1 & 1.5 & 1.8 & BDL & 3.3 \\
\hline BATCH 3-2-7-2 & 1.5 & 2.1 & BDL & 3.6 \\
\hline AVERAGE & 1.5 & 1.6 & & 3.1 \\
\hline STANDARD DEV & 0.0 & 0.5 & & 0.5 \\
\hline BATCH 4-1-7-1 & 2.6 & 1.0 & BDI & 3.6 \\
\hline BATCH 4-1-7-2 & 2.6 & 0.7 & BDL & 3.3 \\
\hline BATCH 4-2-7-1 & 2.5 & BDL & BDL & 2.5 \\
\hline BATCH 4-2-7-2 & 2.5 & 0.8 & BDL & 3.3 \\
\hline AVERAGE & 2.6 & 0.8 & & 3.2 \\
\hline STANDARD DEV & 0.1 & 0.2 & & 0.5 \\
\hline HM-1-7-1 & 0.7 & 1.6 & BDL & 2.3 \\
\hline HM-1-7-2 & 0.6 & 1.7 & BDL & 2.3 \\
\hline HM-2-7-1 & 0.5 & 2.6 & BDL & 3.1 \\
\hline HM-2-7-2 & 0.5 & 2.7 & BDL & 3.2 \\
\hline AVERAGE & 0.6 & 2.2 & & 2.7 \\
\hline STANDARD DEV & 0.1 & 0.6 & & 0.5 \\
\hline PX-1-7-1 & BDL & BDL & 1.7 & 1.7 \\
\hline PX-1-7-2 & BDL & BDL & 1.4 & 1.4 \\
\hline PX-2-7-1 & BDL & BDL & 1.2 & 1.2 \\
\hline PX-2-7-2 & BDL & BDL & 1.3 & 1.3 \\
\hline AVERAGE & & & 1.4 & 1.4 \\
\hline STANDARD DEV & & & 0.2 & 0.2 \\
\hline DETECTION LIMITS & 0.4 & 0.4 & 0.5 & \\
\hline
\end{tabular}

*Data in WSRC-NB-91-198: Data for Nepheline volume percent is calculated. 


\section{Table 4.}

Comparison of Phases Identified in Simulated Canister Centerline-Cooled WCP Glasses Determined by Scanning Electron Microscopy (SEM) and X-ray Diffraction Analysis (XRD)

\begin{tabular}{lll} 
WCP Glass & \multicolumn{2}{c}{ XRD Phases Identified* } \\
\hline Blend 1 & Spinel + Acmite & Spinel + tr. Acmite \\
Batch 1 & Spinel + Acmite & Spinel + Acmite \\
Batch 2 & Spinel + Acmite & Spinel + Acmite \\
Batch 3 & Spinel + Acmite & Spinel + Acmite + $\mathrm{RuO}_{2}$ \\
Batch 4 & Spinel + Acmite & Spinel + Acmite \\
HM & Spinel + Acmite & Spinel + Acmite + $\mathrm{RuO}_{2}$ \\
Purex & Nepheline & Spinel + Acmite + $\mathrm{RuO}_{2}$
\end{tabular}

*Data in WSRC-NB-92-124 
The SEM analysis indicated that the nominal composition of the $\mathrm{NiFe}_{2} \mathrm{O}_{4}$ was enriched in $\mathrm{Ti}$ and $\mathrm{Mn}$ (Figure 2a ). The nominal composition of the $\mathrm{NaFeSi}_{2} \mathrm{O}_{6}$ acmite was enriched in $\mathrm{Cr}$, $\mathrm{Ti}$, and $\mathrm{K}$ (Figure 2b). The SEM analysis also confirmec the crystallization was heterogeneous in that the spinel formed on melt insolubles such as $\mathrm{RuO}_{2}$ while the acmite nucleated on the spinel (Figure 3). This sequence of heterogeneous nucleation was observed in previous studies. ${ }^{7-10}$

\section{Product Consistency Test}

\section{Multielement Standard Analysis}

During PCT analysis, a multielement solution standard was used to ensure that instrumental drift did not significantly bias the short term analysis of the leachates. The multielement solution standard was run befor leachate analysis began and after every 5 leachate samples (Appendix I). Analysis of the solution standard data indicated that there was less than $0.5 \mathrm{ppm}$ bias in the ICP analyses for $\mathrm{B}, \mathrm{Li}, \mathrm{K}, \mathrm{Fe}$, a less than $0.75 \mathrm{ppm}$ bias in $\mathrm{Na}$ and $\mathrm{Al}$ and a greater than $5 \mathrm{ppm}$ low bias for $\mathrm{Si}$ in solution.

\section{Standard Glass Analysis}

Historical control charting using PNL's Approved Reference Material (ARM-1) as the standard glass as the PCT standard glass did not indicate any significant bias in the elemental releases (in ppm) for all elements since May 1989. All the standard glass elemental releases used in this study fell within one-sigma of the average elemental release for ARM-1 glass since May 1989.

\section{WCP Certerline Cooled vs As-Ouenched Glass Analysis}

The leachate $\mathrm{pH}$, the raw data, and the conversions of the ieachate concentanions to $\mathrm{NC}_{\mathrm{i}}(\mathrm{g} / \mathrm{L})$ are given in Tables 5 to 8 for the centerline cooled WCP glasses and for the as quenched WCP glasses. The normalized releases were calculated using the analyzed glass compositions given in Table 1. The normalized releases were calculated in grams of glass (grams of $\mathrm{B}, \mathrm{Li}$, and $\mathrm{Na}$ ) leached per liter of leachate $(\mathrm{g} / \mathrm{L})$ as given in Equation 1. The leach rate enhancement ratio, is also indicated in Tables 6-8 and was calculated from the average durabilities of the crystallized and quenched glasses by the following equation:

$$
\text { leach rate enhancement }=\frac{\text { durability of crystallized glass }}{\text { durability of as quenched glass }}
$$

The leach rate enhancement was minimal, e.g. values of 1.0 to 1.2 except for the high iron (Purex) glass where nepheline was the major crystalline phase to devitrify. The data is shown graphically in Figure 4. The maximum leach rate enhancement for the Purex glass based on the lithium release was 2.2. The range of leach rate enhancements (1-3X) is lower than the factors of 3-5X observed previously. Increased leach rate enhancement in the presence of nepheline, is, however, consistent with the previous studies. ${ }^{7-10}$ 


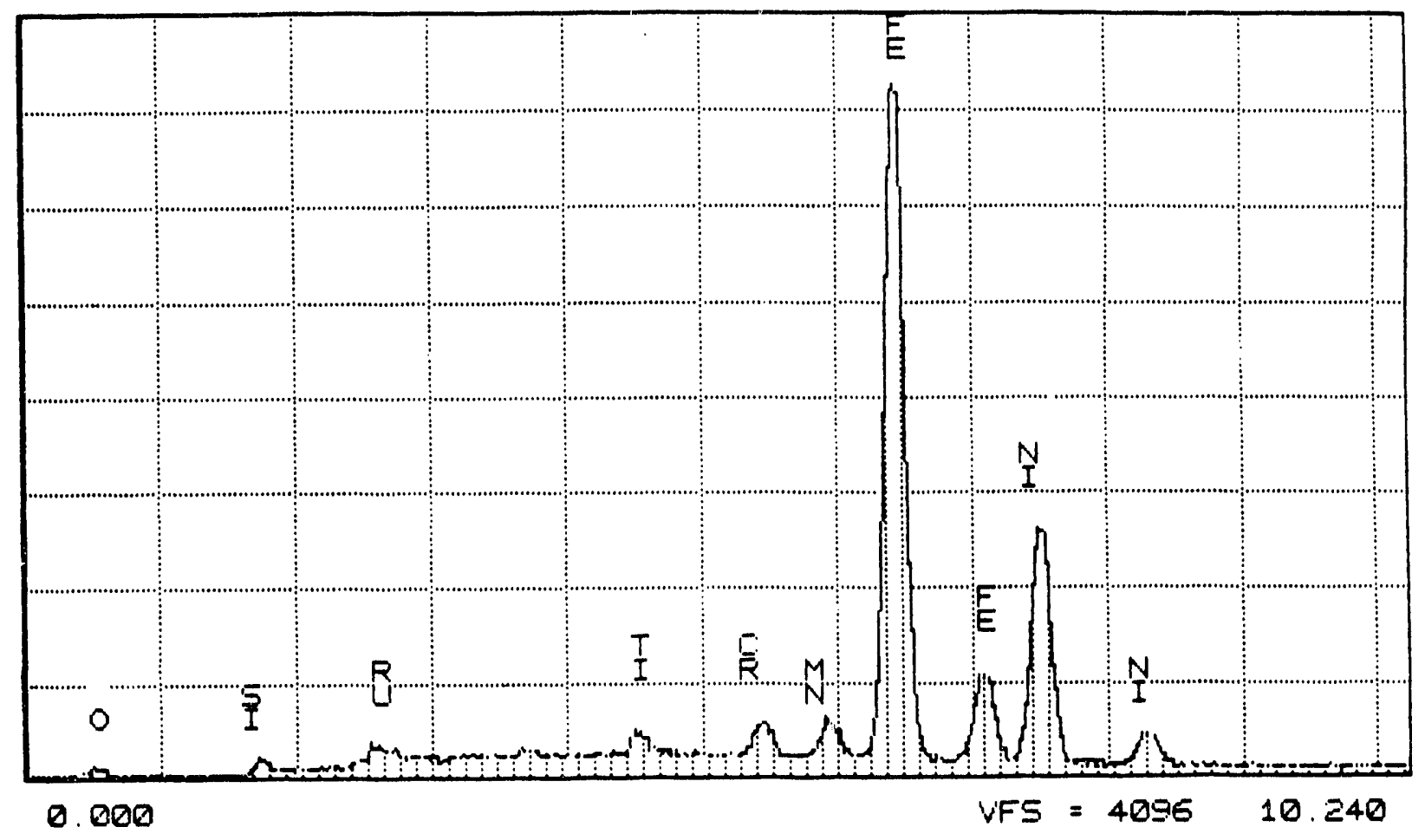

Figure 2a.

SEM/EDAX Analysis of Spinel Phase

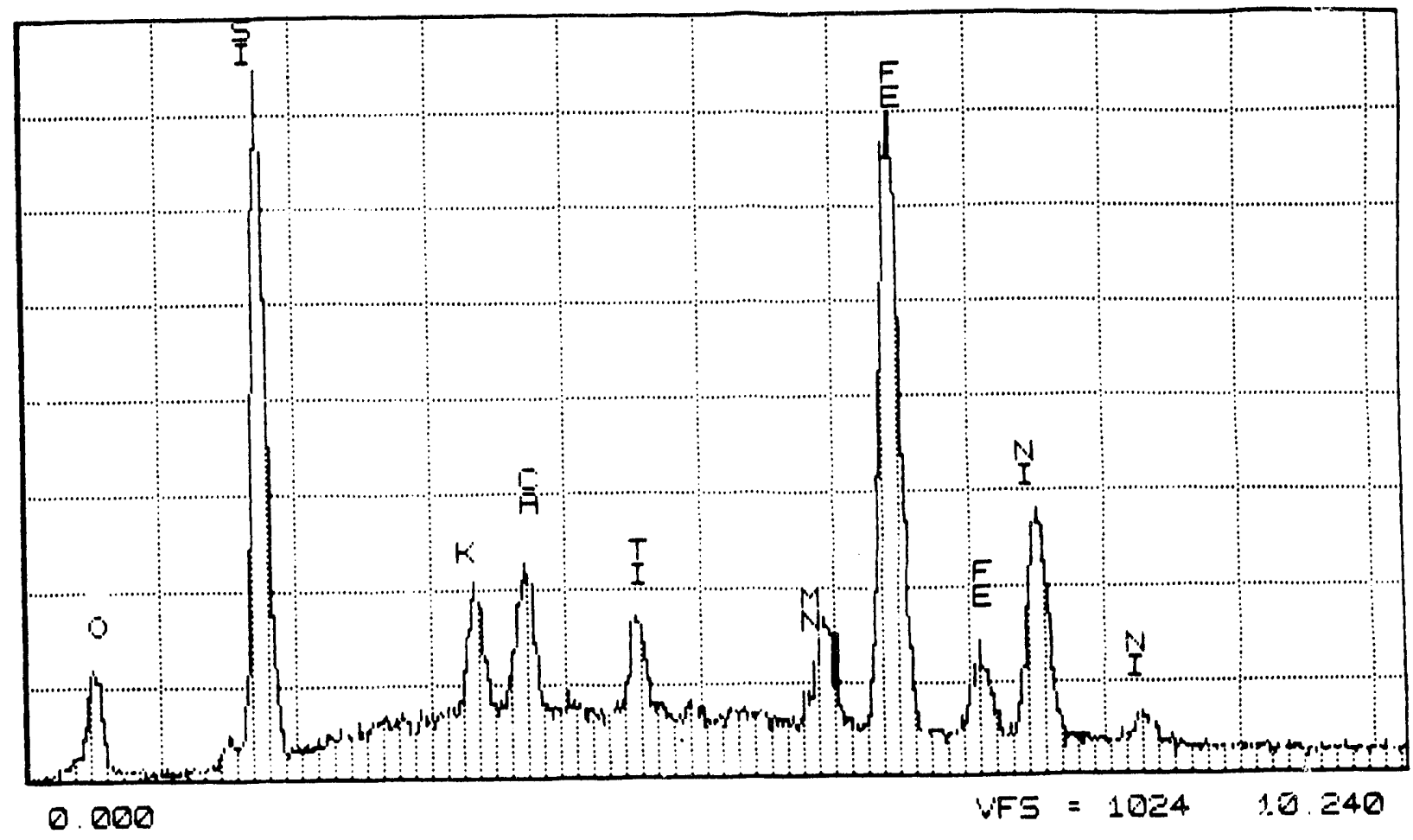

Figure $2 \mathbf{b}$.

SEM/EDAX Analysis of Acmite Phase 


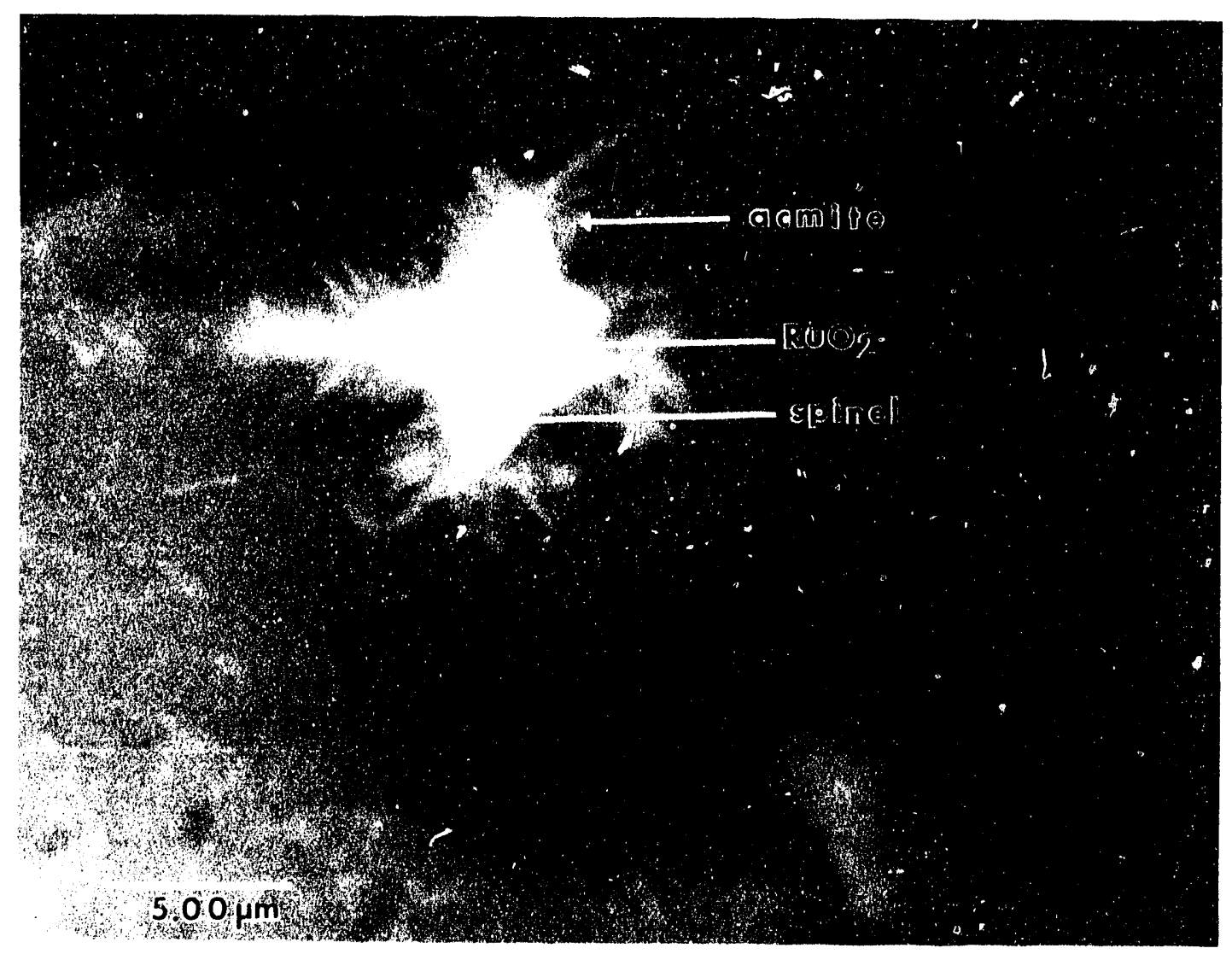

Figure 3.

SEM Micrograph Showing Heterogeneous Nucleation 
Table 5.

Leachate pH for Quenched and Centerline-Cooled DWPF Glasses

\begin{tabular}{|c|c|c|c|c|c|}
\hline CLASS 10 & 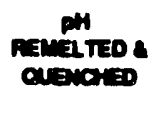 & $\begin{array}{l}\text { PH (ALO) } \\
\text { STANDARO } \\
\text { DEVIATION }\end{array}$ & 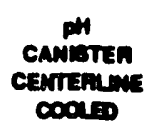 & $\begin{array}{l}\text { H (CC) } \\
\text { STANDANO } \\
\text { DEVIATION }\end{array}$ & 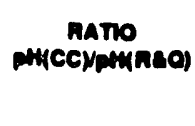 \\
\hline $\begin{array}{l}\text { BLEND } 1.1 .7 .1 \\
\text { BLEND } 1.1 .7-2 \\
\text { BLEND } 1.2 .7-1 \\
\text { BLEND } 1.2 .7 .2 \\
\text { AVEAMES }\end{array}$ & $\begin{array}{l}9.60 \\
9.50 \\
0.61 \\
9.00\end{array}$ & 0.01 & $\begin{array}{l}10.28 \\
10.28 \\
10.34 \\
10.38 \\
10.31\end{array}$ & 0.04 & 1.07 \\
\hline $\begin{array}{ll}\text { BATCH } & 1.1-7.1 \\
\text { BATCH } & 1-1.7-2 \\
\text { BATCH } & 1.2 .7-1 \\
\text { BATCH } & 1.2 .7-2 \\
\text { AVELCE }\end{array}$ & $\begin{array}{l}0.69 \\
0.68 \\
0.64 \\
0.67\end{array}$ & 0.02 & $\begin{array}{l}10.40 \\
10.30 \\
10.38 \\
10.98 \\
10.38\end{array}$ & 0.08 & 1.07 \\
\hline 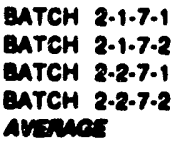 & $\begin{array}{l}9.59 \\
9.63 \\
9.59 \\
9.39\end{array}$ & 0.00 & $\begin{array}{l}10.27 \\
10.00 \\
10.00 \\
10.27 \\
00.14\end{array}$ & 0.10 & 1.00 \\
\hline 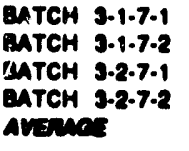 & $\begin{array}{l}0.60 \\
0.54 \\
0.53 \\
0.59\end{array}$ & 0.04 & $\begin{array}{l}10.38 \\
10.00 \\
10.28 \\
10.20 \\
10.87\end{array}$ & 0.10 & 1.08 \\
\hline $\begin{array}{l}\text { BATCH } 4-1.7 .1 \\
\text { BATCH } 4-1.7 .2 \\
\text { BATCH } 4-2.7 .1 \\
\text { BATCH } 4-2.7 .2 \\
\text { ANSCAC }\end{array}$ & $\begin{array}{l}9.67 \\
0.70 \\
0.71\end{array}$ & 0.02 & $\begin{array}{l}10.00 \\
10.47 \\
10.40 \\
10.00 \\
10.84\end{array}$ & 0.28 & 1.00 \\
\hline $\begin{array}{l}\text { MM-1.7.1 } \\
\text { HM-1.7-2 } \\
\text { HM-2.7-1 } \\
\text { HMA-2.7-2 } \\
\text { AWraed }\end{array}$ & $\begin{array}{l}0.97 \\
0.37 \\
9.31\end{array}$ & 0.60 & $\begin{array}{l}10.27 \\
10.20 \\
10.00 \\
10.00 \\
10.14\end{array}$ & 0.10 & 8.60 \\
\hline $\begin{array}{l}\text { PX.1-7.1 } \\
\text { PX-1.7-2 } \\
\text { PX-2.7-1 } \\
\text { PX-2.1-2 } \\
\text { Av: }\end{array}$ & $\begin{array}{l}0.01 \\
0.06 \\
0.10 \\
0.04\end{array}$ & 0.03 & $\begin{array}{l}10.60 \\
10.40 \\
10.00 \\
10.00 \\
10.20\end{array}$ & 0.20 & 1.00 \\
\hline
\end{tabular}

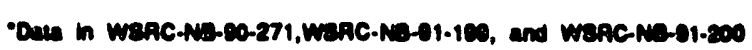




$\vdots \quad \vdots \quad \vdots \quad \vdots$

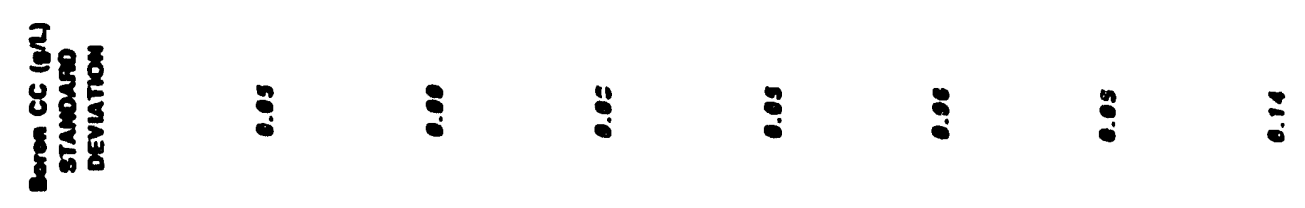

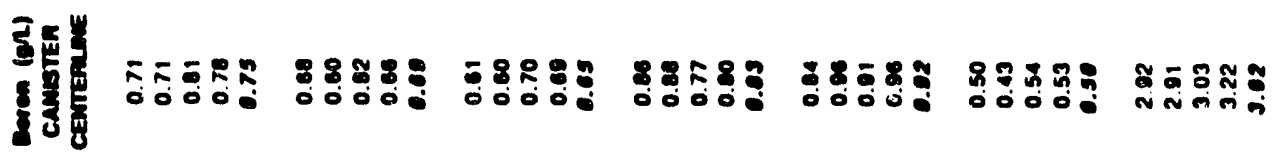
I ไูป

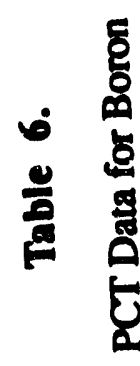

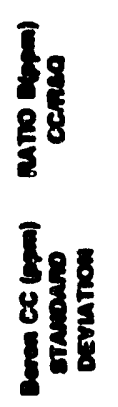

$$
\vdots \quad \vdots \quad \vdots \quad \vdots \quad \vdots
$$

II

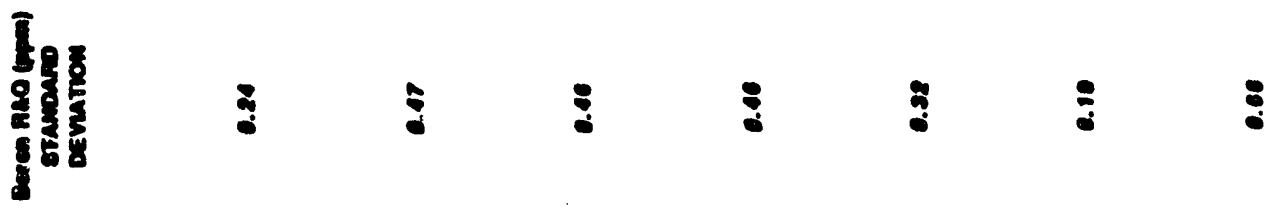

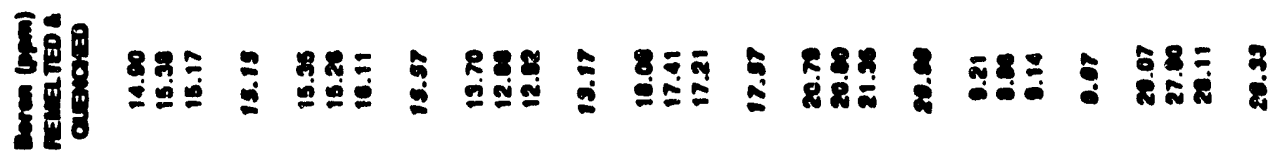

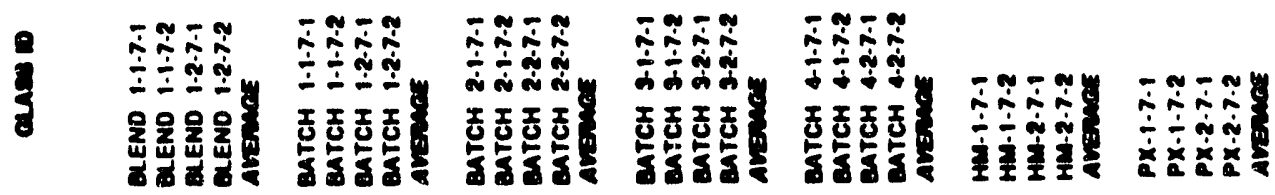




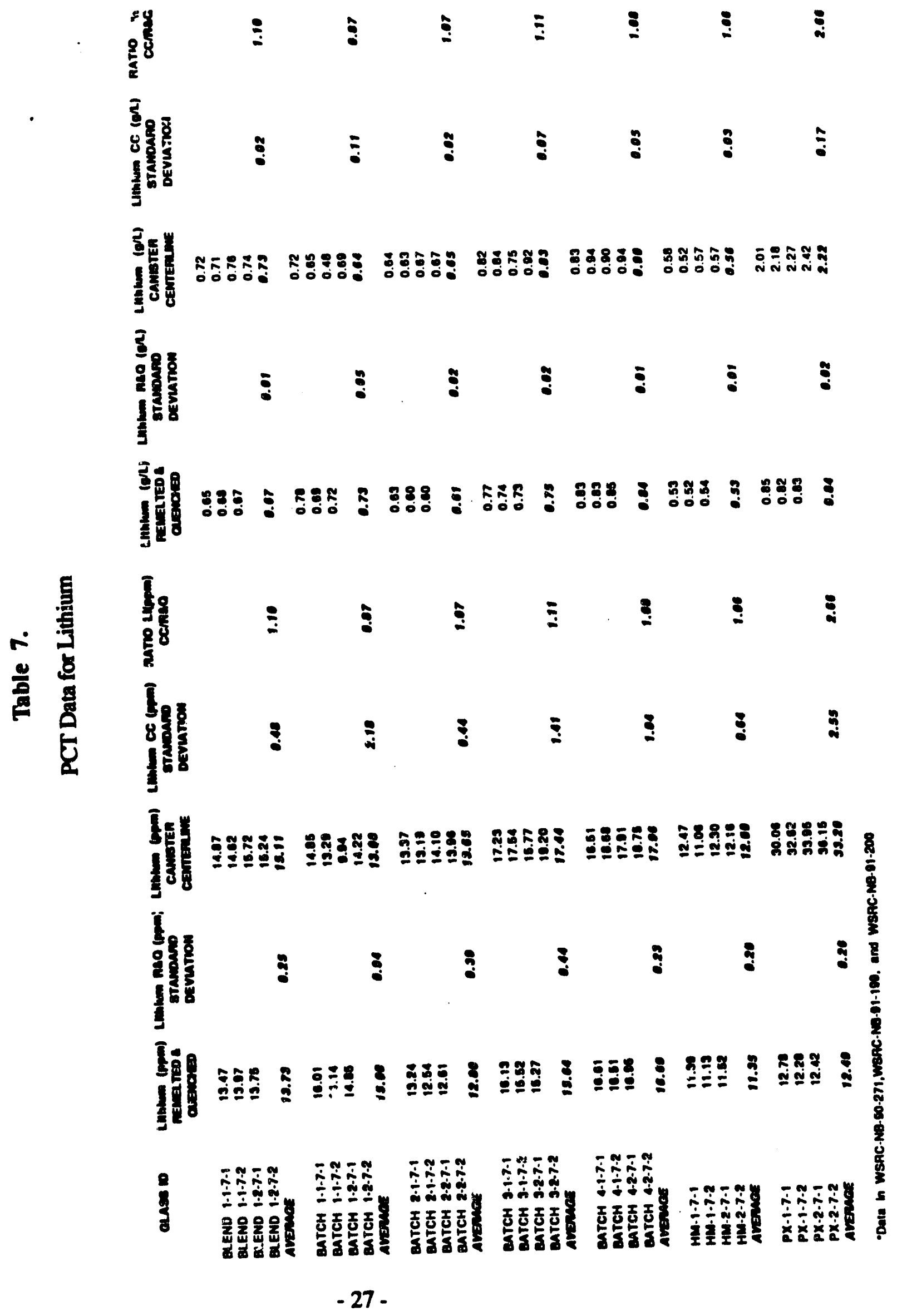




$$
\begin{aligned}
& \begin{array}{l}
3 \\
8 \\
8 \\
8
\end{array}
\end{aligned}
$$

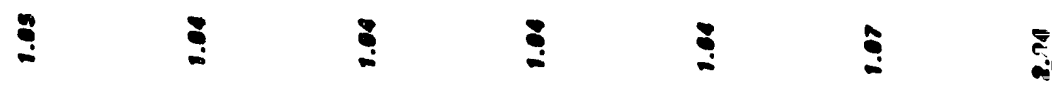

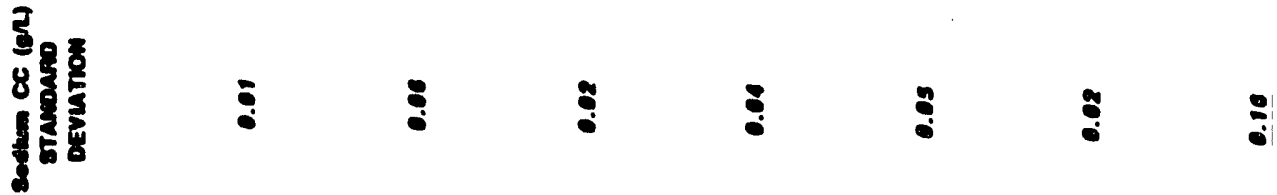

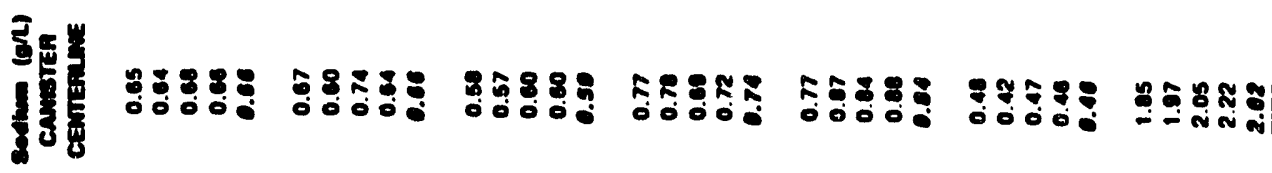

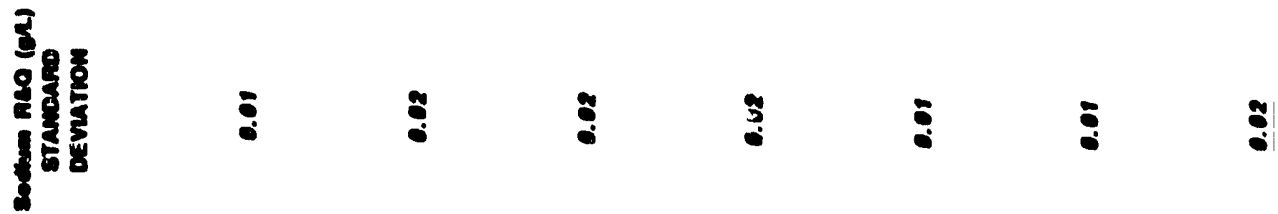

$$
\begin{aligned}
& \text { 政 }
\end{aligned}
$$

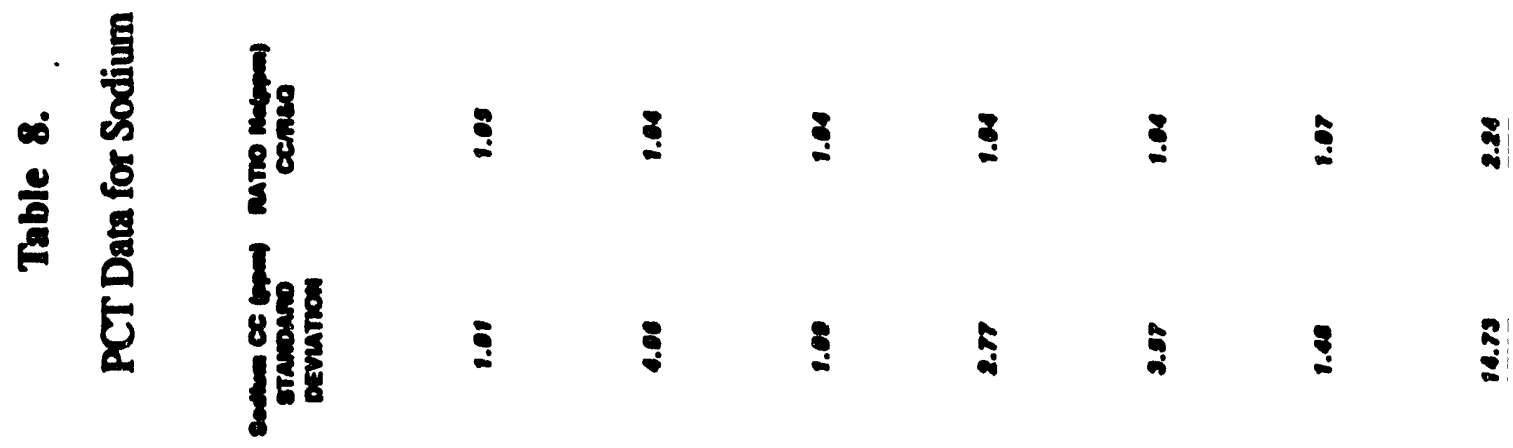

$$
\begin{aligned}
& \text { Iำ }
\end{aligned}
$$

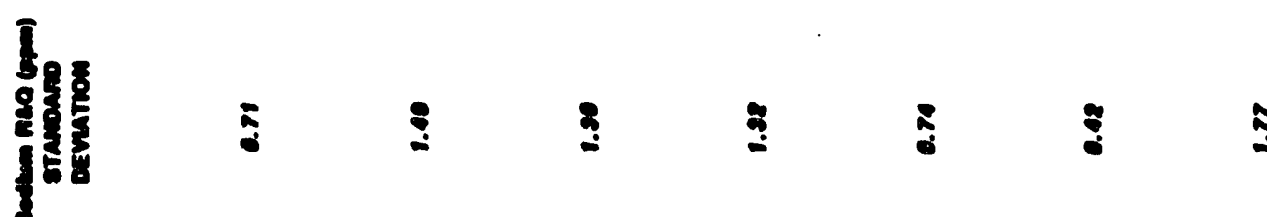

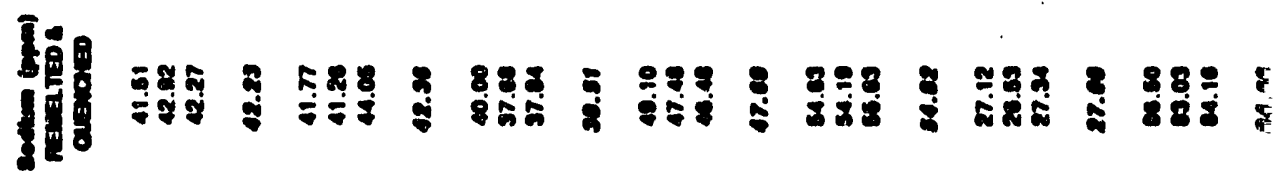

$$
\begin{aligned}
& \text { 年 } \\
& -28 \text { - }
\end{aligned}
$$




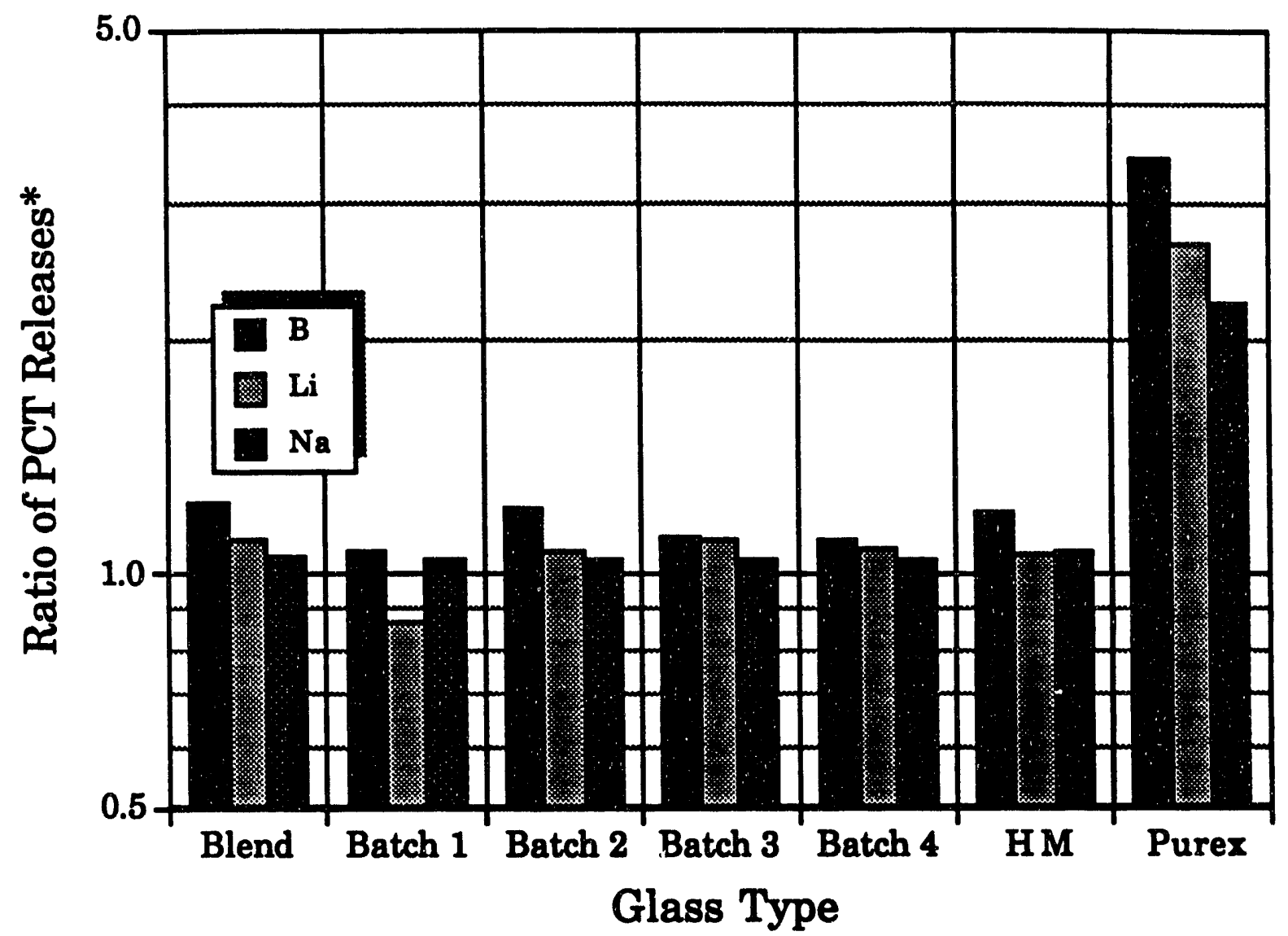

Figure 4.

Effect of Canister Centerline Cooling on PCT Release of DWPF Projected Glasses 
This page intentionally left blank.

$-30-$ 


\section{CONCLUSIONS}

Centerline cooling studies of the seven DWPF projected glass compositions show that while some crystallization does occur during canister cooling it is minimal and concomitantly has a minimal effect on glass durability. These studies of the seven glasses in the WCP have revealed the same phase assemblages as observed in previous studies ${ }^{7-10}$ but a factor of $\sim 10$ less total amount of crystallization. The crystallization mechanism is by heterogeneous nucleation of spinel on melt insolubles such as $\mathrm{RuO}_{2}$ and nucleation of acmite on spinel as observed previously. . $^{7-10}$ The lower volume percentages of total crystallization are attributed to the higher $\mathrm{SiO}_{2}$ content of the family of 202 glasses represented in the WCP compared to the previous 165 and 131 SRS glasses studied. The lower volume percentages of total crystallinity indicate only marginal leach rate enhancement, where

$$
\text { leach rate enhancement }=\frac{\text { durability of crystallized glass }}{\text { durability of as quenched glass }}
$$

Leach rate enhancements of 1.00 to 1.25 were observed for all the WCP glasses except for the high iron containing Purex glass where leach rate enhancements of up to 3.4 were observed. The larger leach rate enhancement was associated with the crystallization of nepheline as observed in previous studies. ${ }^{7-10}$

\section{QUALITY ASSURANCE}

The SRL Glass Technology Task Control Matrix for all the tasks in this study is given in Reference 26. All tasks were carried out in accordance with RW-0214 and NQA-1. The PCT Version 3.0 is a Glass Technology Category 1 Procedure requiring experimenter data input and signoff at every step. ${ }^{18}$ All the ovens, balances, and water purification systems used for the PCT are M\&TE Category 1.

Analytic Development Services (SRL/ADS) procedures were followed for all chemical analyses.

Glass fabrication and analyses are recorded in DPSTN-4771 and WSRC-NB-90-392. All the heat treatment data for this study is recorded in WSRC-NB-90-229. The quantitative x-ray diffraction analyses and the scanning electron microscopy analyses are recorded in WSRCNB-91-198 and WSRC-NB-92-124. All the PCT data and analyses for the centerline cooled glasses are recorded in WSRC-NB-90-271 and WSRC-NB-91-199. All the PCT data and analyses for the as quenched glasses is recorded in WSRC-NB-91-200. 
This page intentionally left blank.

-32 . 


\section{REFERENCES}

1. Office of Civilian Radioactive Waste Management, Waste Acceptance Preliminary Specifications for Vitrified High-Level Waste Forms, DRAFT, June 1991.

2. Waste Form Compliance Plan for the Defense Waste Processing Facility, Revision 0, USDOE Document WSRC-SW4-6, Westinghouse Savannah River Company, Aiken, SC, March 1990.

3. M.J. Plodinec, "Vitrification Chemistry and Nuclear Waste,"J. Non-Cryst. Solids, 84, pp. 206-14, 1986.

4. D.J. Pellarin, "DWPF Canister and Glass Temperatures During Filling and Cooldown", USDOE Report DPST-85-954, Savannah River Laboratory, E.I. du Pont de Nemours and Co., Aiken, SC, 1985.

5. R.E. Edwards, "SGM Run 8 - Canister and Slass Temperatures During Filling and Cooldown", USDOE Report DPST-87-801, Savannah River Laboratory, E.I. du Pont de Nemours and Co., Aiken, SC, 1987.

6. S.L. Marra, "Qualification of Data on Glass Temperatures During Canister Filling and Cooldown", USDOE Report WSRC-RD-91-13, Westinghouse Savannah River Company, Aiken, SC, 1991.

7. C.M. Jantzen, D.F. Bickford, and D.G. Karraker, "Time-TemperatureTransformation Kinetics in SRL Waste Glass," Advances in Ceramics, Vol. 8, G.G. Wicks and W.A. Ross (Eds.), American Ceramic Society, Westerville, OH, 30-38, 1984.

8. D.F. Bickford and C.M. Jantzen, "Devitrification Behavior of SRL Defense Waste Glass," Scientific Basis for Nuclear Waste Management, VII, G.L. McVay (Ed.), Materials Research Society Proceedings, Vol. 26, Elsevier Science Pub. Inc., New York, 557-566, 1984.

9. C.M. Jantzen and D.F. Bickford, "Leaching of Devitrified Glass Containing Simulated SRP Nuclear Waste," Scientific Basis for Nuclear Waste Managment, VIII, C.M. Jantzen, et. al. (Eds.), Materials Research Society, Pittsburgh, PA, 135-146, 1985.

10. D.F. Bickford and C.M. Jantzen, "Devitrification of Defense Nuclear Waste Glasses: Role of Melt Insolubles,"J. Non-Cryst. Solids, 84, 299-307, 1986.

11. D.M. Strachan, B.O. Barnes, R.P. Turcotte, "Standard Leach Tests for Nuclear Waste Materials," Scientific Basis for Nuclear Waste Managment, III, J.G. Moore (Ed.), Plenum Press, New York, 347-354, 1981.

12. C. M. Jantzen and N. E. Bibler, "Product Consistency Test (PCT) and Test Protocol," USDOE Report DPST-87-575, Savannah River Laboratory, E.I. du Pont de Nemours and Co., Aiken, SC, 1987. 
13. G. F. Piepel, T. E. Jones, D. L. Eggett, G. B. Mellinger, "Product Consistency Test Round Robin Conducted by the Materials Characterization Center - Summary Report," USDOE Report PNL-6967, Materials Characterization Center, Battelle Pacific Northwest Laboratories, Richland, WA, 1989.

14. N. E. Bibler and J. K. Bates, "Product Consistency Leach Tests of Savannah River Site Radioactive Waste Glasses,"Scientific Basis for Nuclear Waste Management, XIII, V. M. Oversby and P. W. Brown (Eds.), Materials Research Society, Pittsburgh, PA, 327-338, 1990.

15. N.E. Bibler and C.M. Jantzen, "The Product Consistency Test and Its Role in the Waste Acceptance Process," Waste Management 89 Proceedings, I., 743-749, 1989.

16. C.M. Jantzen and N.E. Bibler. "The Product Consistency Test for the DWPF Wasteform," Requirements for Waste Acceptance and Quality Control, Proceedings of the 2nd International Seminar on Radioactive Waste Products, E. Warnecke, R. Odoj, and R. Simon (Eds.) Kerforschunganlanger (KFA) Research Centre, Julich, Federal Republic of Germany, 610-622, 1990.

17. C.M. Jantzen, "Evaluation of Experimental Factors That Influence the Application and Discrimination Capability of the Product Consistency Test," U.S. DOE Report WSRCTR-90-526, Westinghouse Savannah River Company, Aiken, SC, 1990.

18. C.M. Jantzen and N.E. Bibler, "Nuclear Waste Product Consistency Test (PCT) - Version 3.0," USDOE Report WSRC-TR-90-539, Rev. 1, Westinghouse Savannah River Company, Aiken, SC, November, 1990.

19. C.M. Jantzen, "Glass Compositions and Frit Formulations Developed for DWPF," USDOE Report DPST-88-952, Savannah River Laboratory, E.I. du Pont de Nemours and Co., Aiken, SC, November, 1988.

20. Phase Diagrams for Ceramists, American Ceramic Society, Inc., Columbus, $\mathrm{OH}$, Figure 501, p. 181, 1964.

21. F.H. Chung, "Quantitative Interpretation of X-Ray Diffraction Patterns of Mixtures. I. Matrix Flushing Method for Quantitative Multieomponent Analysis." J. Appl. Cryst., 7, 519-525, 1974.

22. F.H. Chung, "Quantitative Interpretation of X-Ray Diffraction Patterns of Mixtures. II. Adiabatic Principle of X-RAY Diffractin Analysis of Mixtures." J. Appl. Cryst., 7, 526-531, 1974.

23. F.H. Chung, "Quantitative Interpretation of X-Ray Diffraction Patterns of Mixtures. III. Simultaneous Determination of a Set of Reference Intensities." J. Appl. Cryst., 8, $17-19,1975$.

24. B.D. Cullity, Elements of X-Ray Diffraction, Addison-Wesley Publishing, Inc., Reading, MA, 1967.

25. Joint Committee on Powder Diffraction Standards, JCPDS \#10-325, Swarthmore, PA. 
26. Joint Committee on Powder Diffraction Standards, JCPDS \#18-1222, Swarthmore, PA.

27. S.L. Marra, "Research and Development Plan Phase Stability Determinations," USDOE Report WSRC-TR-90-540 Rev. 1, Westinghouse Savannali River Company, Aiken, SC, September, 1991.

28. C.M. Jantzen, "First Principles Process-Product Models for Vitrification of Nuclear Waste: Relationship of Glass Composition to Glass Viscosity, Resisitivity, Liquidus Temperature, and Durability,"Ceramic Transactions - Nuclear Waste Management IV, G.G. Wicks, D.F. Bickford, and L.R. Bunnell (Eds.), American Ceramic Society, Westerville, OH, 1991. 
This page intentionally left blank.

$-36-$ 
ป⿱艹

in

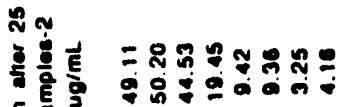

娄

D-

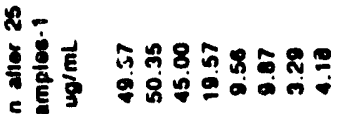

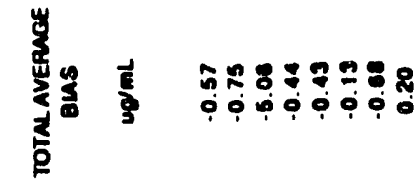
बक

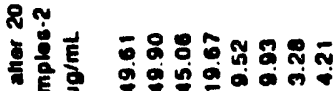

क्ष

ฉ -

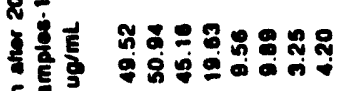

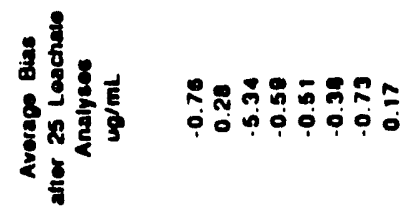

दूर

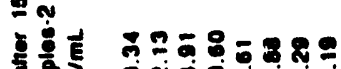

दै

$\therefore-$

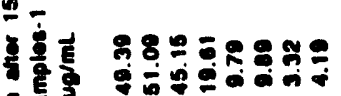

这尔

क

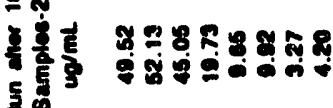

올

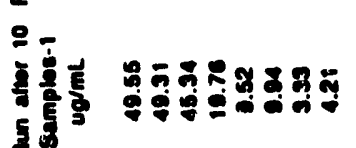

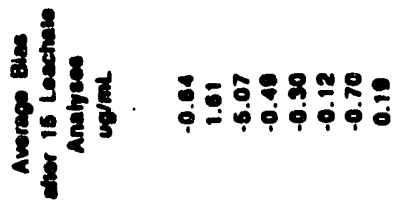

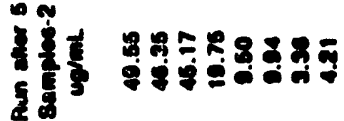

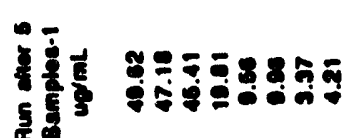

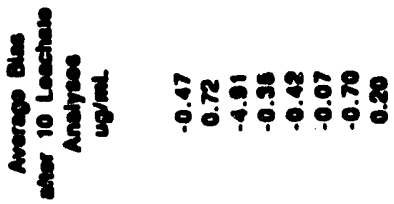

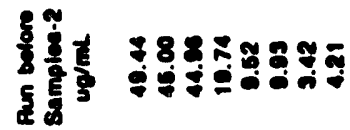

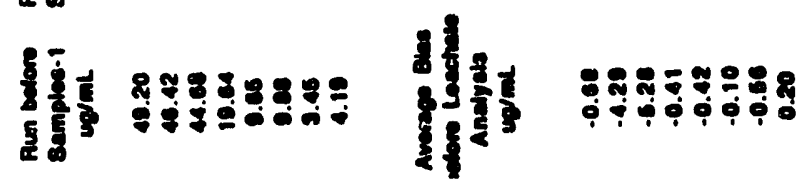

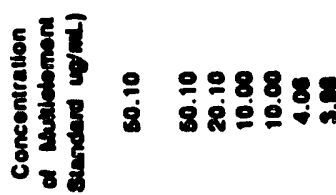

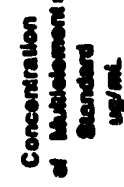

हुำ

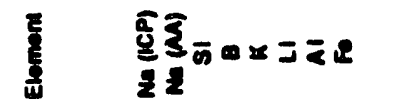

8

89.8888
$8985+4$

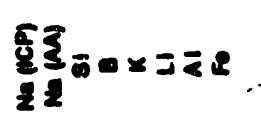


This page intentionally left blank.

- 38 - 


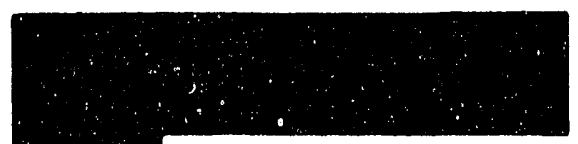

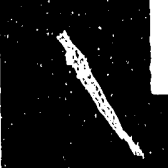
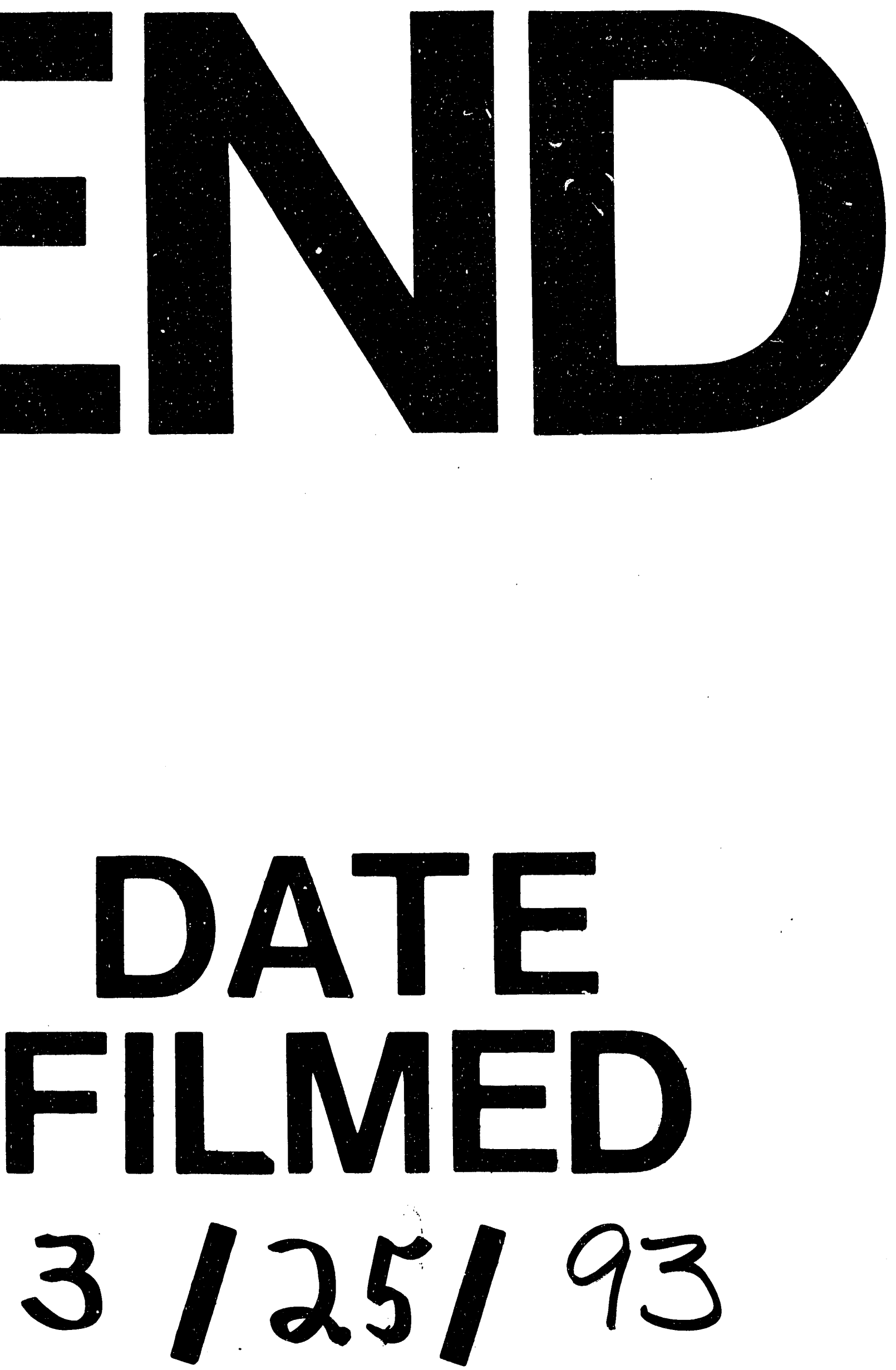
11 